\title{
Microbiological species and antimicrobial resistance profile in patients with diabetic foot infections
}

\section{Perfil microbiológico e de resistência antimicrobiana no pé diabético infectado}

Alexandre Faraco de Oliveira', Horácio de Oliveira Filho²

\begin{abstract}
Introduction: Diabetic foot infections are a difficult problem to solve, often requiring hospitalization and exposing patients to the risk of amputations. Identification of the most prevalent pathogens is useful for administration of antibiotic therapy, and can reduce mutilations. Objective: To identify the microbiological profile and resistance to antimicrobial drugs in a series of patients with infected diabetic feet. Material and methods: an epidemiological, retrospective and descriptive study based on analysis of medical records from diabetic patients with plantar lesions who underwent surgical treatment over a 24-month period at a public hospital. Data were collected on age, sex, length of hospital stay, cultures from lesions, antibiotic therapy administered, bacterial resistance and surgeries conducted, with statistical analysis of means and standard deviations. Results: There were 66 admissions of diabetic patients, the majority elderly people (77\%). Hospital stays ranged from 2 to 29 days, with a mean of 12.42. There were 91 surgical procedures, resulting in some kind of amputation in $65 \%$ of cases. The most common bacterial group was enterobacteria (47\%), followed by staphylococci (27\%). Three patients (4.5\%) had multi-resistant organisms. Resistance to clindamycin was the most common at 39 admissions (59\%), followed by resistance to cephalexin, seen in 24 admissions (36\%).

Conclusions: Diabetic foot infections were most often caused by germs found in the community, in particular the enterococci. Bacterial resistance was very widespread and was most commonly associated with drugs for oral administration, in particular clindamycin and cephalexin.
\end{abstract}

Keywords: diabetic foot; bacterial drug resistance; diabetes complications.

\begin{abstract}
Resumo
Introdução: As infecções no pé diabético são um problema de difícil solução, que costumam exigir internação hospitalar e expõem os pacientes ao risco de amputações. Determinar os patógenos mais prevalentes auxilia na escolha de antimicrobianos, podendo reduzir mutilações. Objetivo: Determinar o perfil microbiológico e a resistência a antimicrobianos em uma série de pacientes com pé diabético infectado. Material e métodos: estudo epidemiológico, retrospectivo e descritivo, através da análise de prontuários de pacientes diabéticos, com lesões plantares, submetidos a tratamento cirúrgico, num período de 24 meses, em um hospital público. Foram coletados dados referentes a idade, sexo, tempo de internamento, cultura da lesão, antimicrobianos utilizados, resistência bacteriana e cirurgias realizadas, com análise estatística da média e desvio padrão. Resultados: Em 66 internações de pacientes diabéticos, na maioria de idosos (77\%), o tempo de internação variou de 02 a 29 dias, com média de 12,42; exigiram-se 91 procedimentos cirúrgicos, resultando algum tipo de amputação em $65 \%$ dos casos. $\mathrm{O}$ grupo de bactérias mais frequente foi das enterobactérias (47\%), seguido por estafilococos (27\%). Três pacientes (4,5\%) apresentaram germes multirresistentes. Dentre os antimicrobianos utilizados, a clindamicina foi o que apresentou resistência no maior número de vezes, em 39 internações (59\%), seguido da cefalexina, em 24 internações (36\%). Conclusões: As infecções no pé diabético estiveram mais relacionadas a germes encontrados na comunidade, em especial os enterococcus. A resistência bacteriana foi bastante ampla, sendo mais comumente associada a drogas de uso oral, em particular clindamicina e cefalexima.
\end{abstract}

Palavras-chave: pé diabético; farmacorresistência bacteriana; complicações do diabetes.

\footnotetext{
'Universidade do Planalto Catarinense - UNIPLAC, Lages, SC, Brazil.

${ }^{2}$ Clínica Ana Carolina Lages, Lages, SC, Brazil.

Financial support: None.

Conflicts of interest: No conflicts of interest declared concerning the publication of this article

Submitted: 02.04.14. Accepted: 07.10.14.
} 


\section{INTRODUCTION}

Diabetic patients are exposed to risks of developing a range of different complications in multiple systems. Diabetic plantar lesions are generally the result of a series of metabolic, vascular and neuropathic abnormalities that act in synergy, affecting patients' feet. ${ }^{1,2}$ These abnormalities provide the conditions for a chain of events which comprise an increased propensity to develop skin lesions and a reduced likelihood the lesions will heal, exposing the patient to the risk of infections, which can sometimes be severe and extensive. ${ }^{3}$

Efforts should be concentrated on achieving early diagnosis of infection of diabetic ulcers, because infection is associated with up to 56 times greater risk of hospital admissions and up to 155 times the risk of amputation. ${ }^{4,5}$ In addition to the suffering inflicted on patients, hospital treatment of the diabetic foot tends to be of high cost to the healthcare system. Even after hospital discharge, these patients generally require permanent care and, sometimes, repeated admissions to treat the same problem. ${ }^{6}$

While there are protocols to guide administration of antimicrobial treatments for the diabetic foot empirically, knowledge of the microbiota in a given region and, better still, a specific hospital, can make a decisive contribution to choosing the most appropriate antimicrobial, which in turn has a direct impact on treatment success. ${ }^{3,4}$ In this study we attempted to identify the most prevalent germs and to profile their antimicrobial resistance at a public hospital in the interior of the state of Santa Catarina, Brazil.

\section{MATERIALS AND METHODS}

We conducted a retrospective epidemiological study by means of analysis of medical records for patients admitted to a medium complexity public hospital for treatment of vascular diseases over a 24-month period from January 2011 to December 2012. We were granted authorization to conduct this research by the hospital and the study was approved by the Research Ethics Committee, under protocol number 044/12.

We searched registry data from the surgery department to produce a list of all patients subjected to treatment with vascular surgery. From this list, patients were selected who had undergone surgical procedures that can be used to treat the diabetic foot, including: debridement, fasciotomy, minor and major amputations, surgical dressing and cleaning.
We selected for the sample, consecutively, all medical records containing notes indicating that patients had diabetes mellitus and had undergone surgical treatment for lesions characteristic of the diabetic foot, even if these lesions have not been classified as a specific type of ulcer.

We considered patients to have had lesions characteristic of the diabetic foot if their medical records described peripheral neuropathy, in the form of notes describing symptoms such as paresthesia/ hypoesthesia/anesthesia, and/or signs such as plantar or toe deformities (claw toes, hammer toes), painless ulcerations and plantar ulcerations, or the results of specific tests for neuropathy, such as insensitivity to $10 \mathrm{~g}$ monofilament, abnormal $128 \mathrm{~Hz}$ tuning fork test and abolition of the Achilles reflex.

Ten patients were excluded because they had macrovascular injuries diagnosed by Doppler ultrasonography and needed surgical and/or endovascular treatment for these lesions and were referred for treatment at a high complexity center.

During review of the medical records, data were noted on age, sex, length of hospital stay, cultures from lesions, antimicrobials prescribed, bacterial resistance and surgery conducted. In all cases the samples for cultures were collected during the surgical procedure, by means of biopsy of the infected area after prior cleaning, with preference given to bone and tendon tissues. Material was collected into sterile flasks containing saline solution and immediately transported to the laboratory. Manual methods were used both for culturing and for constructing antibiograms, employing the following culture mediums: MacConkey, agar chocolate, agar blood and CLED agar. Culture mediums for anaerobic germs were not available. Statistical analysis of data consisted of calculation of means and standard deviations.

\section{RESULTS}

A total of 66 admissions met the criteria for relevance to the study objectives and were selected and subjected to analysis. Two patients were admitted twice, one patient was admitted three times and one patient was admitted six times, so that these 66 admissions related to a total of 57 patients, 27 of whom were men and 30 of whom were women. There was a predominance of elderly people: $44(77 \%)$ of 57 patients were over 60 years old; these 44 patients had a mean age of 65 years. Length of hospital stay varied from 2 to 29 days, with a mean of 12.42 and standard deviation of 6.67 days. 
The patients needed 91 surgical procedures, resulting in some type of amputation in $65 \%$ of cases. The most common bacterial group was enterobacteria (47\%), followed by staphylococcus $(27 \%)$. Three patients $(4.5 \%)$ had infections by multi-resistant Staphylococcus aureus (Table 1).

A large number of different antimicrobial were prescribed (Table 2), and of these, 39 admissions (59\%) exhibited resistance to clindamycin and in 24 admissions resistance to cephalexin was detected $(36 \%)$.

\section{DISCUSSION}

The patient profile observed here, predominantly elderly people, and also the high rate of amputations among the surgical treatments required, have also been reported by other studies that have focused on epidemiology of patients with diabetic feet. ${ }^{7}$ These results are therefore expected, considering that the complications of diabetes primarily affect those who live with the disease for longer periods. ${ }^{2}$

Among diabetic patients, there is little evidence for clinical diagnosis of infection. Many different factors, including peripheral artery disease, neuropathy and reduced leukocyte activity, contribute to an impaired inflammatory response and, as a result, inflammatory signs and symptoms can sometimes be discreet and out of proportion to the severity of infection. ${ }^{4,8}$ These factors, in combination with the anatomic characteristics of the foot, are also involved in the risk of rapid progression of infections. . Serological markers, such as tests of inflammatory activity and

Table 1. Bacteria found in cultures of deep samples from patients with infected diabetic feet $(n=66)$.

\begin{tabular}{lccc}
\hline \multicolumn{1}{c}{ Species of bacteria } & $\mathrm{n}$ & $\%$ & Bacterial group \\
\hline Staphylococcus aureus & 15 & 22.7 & Staphylococcus 27.2 \\
$\begin{array}{l}\text { (Multi resistant) } \\
\text { Staphylococcus aureus }\end{array}$ & 03 & 4.5 & \\
Escherichia coli & 05 & 7.5 & Enterobacteria 48.1 \\
Proteus vulgaris & 09 & 13.6 & \\
Proteus mirabilis & 06 & 9.0 & \\
Enterobacter aglomerans & 06 & 9.0 & \\
Klebsiella ozaenae & 02 & 3.0 & \\
Klebsiella oxytoca & 01 & 1.5 & \\
Yersinia pseudotuberculosis & 03 & 4.5 & \\
Pseudomonas aeruginosas & 06 & 9.0 & \\
Acinetobacter baumannii & 07 & 10.6 & \\
Aeromonas hydrophila & 01 & 2.3 \\
No bacterial growth & 11 & 16.6 \\
\hline Note: more than one type of germ was identified in the majority of samples \\
collected.
\end{tabular}

white blood counts, tend to offer low sensitivity and specificity. ${ }^{4}$

However, even though clinical features indicating local infection may present in a subtle form, they still remain the best method for diagnosing infection in the diabetic foot and can also be used to quantify the degree of infection, as proposed by the International Working Group on the Diabetic Foot (IWGDF).,10 Once diagnosis has been confirmed, in addition to surgical procedures and local cleaning, treatment generally requires aggressive and wide-spectrum antimicrobial treatment, which is initially chosen on an empirical basis or using previously-establish protocols. ${ }^{8}$

We must take special care to observe the criteria related to taking cultures from lesions to diagnose infectious processes. Since these wounds tend to be colonized by a range of microorganisms, definition of infection should be guided by clinical criteria and not by simply demonstrating growth of microorganisms in culture. ${ }^{4,9,11}$ A critical value for colonizing bacteria of around 100,000 colonies has been proposed; however, it has also been demonstrated that more virulent pathogens, even when in smaller numbers,

Table 2. Resistance to antimicrobial drugs used in treatment of patients with infected diabetic feet.

\begin{tabular}{lll}
\hline \multicolumn{1}{c}{ Antimicrobial } & $\mathrm{n}$ & $\%$ \\
\hline Clindamycin & 39 & 59.0 \\
Cephalexin & 24 & 36.3 \\
Ampicillin/Sulbactam & 23 & 34.8 \\
Sulfamethoxazole/Trimethoprim & 22 & 33.3 \\
Aztreonam & 21 & 31.8 \\
Ciprofloxacin & 19 & 28.7 \\
Cefuroxime & 18 & 27.2 \\
Ceftriaxone & 16 & 24.2 \\
Levofloxacin & 16 & 24.2 \\
Ceftazidime & 15 & 22.7 \\
Gentamycin & 15 & 22.7 \\
Norfloxacin & 15 & 22.7 \\
Ampicillin & 10 & 15.1 \\
Cefepime & 09 & 13.6 \\
Chloramphenicol & 06 \\
Cephalothin & 09 & 13.6 \\
Cefotaxime & 06 & 9.0 \\
Ertapenem & 06 & 9.0 \\
Meropenem & 06 & 9.0 \\
Piperacillin/Tazobactam. & 9.0 \\
Erythromycin & 06.5 \\
Imipenem & 7.5 \\
Oxacillin & 06 & 7.5 \\
\hline
\end{tabular}


have greater potential to damage tissues than less virulent strains, even when colonizing the same tissues. ${ }^{12,13}$ The objective is that by taking a sample from the wound, the bacteria that is probably responsible for the infection will be identified, rather than to achieve a simple proof of presence or absence of infection.

Culture collection technique is an important point, as has been shown in a study published by Sotto et al.. ${ }^{14}$ Care should be taken to avoid collecting superficial samples, preferring samples from deeper tissues (biopsy or curettage). The result tends to be a reduction in the number of pathogens identified. Graham negative bacilli become less frequent and gram-positive cocci become more prevalent. Primarily, the number of multi-resistant germs tends to reduce. Bacteria considered commensal become more prevalent. Therefore, the treatment chosen is more likely to be appropriate, which tends to be reflected in reductions in amputation rates and treatment costs. ${ }^{14}$

Medical societies have published a range of different protocols for initial empirical treatment of infection of the diabetic foot, but identification of the most prevalent microbiota in each country, region and hospital can be a useful guide to physicians in choosing the most appropriate drug. Similarly, it is also desirable to accumulate knowledge on the profile of resistance to the antibiotics most often employed. . $, 2,14^{2}$

In the sample described here, there was a predominance of germs that are common outside of hospital settings and are present in patients' flora (enterococcus and staphylococcus), according to previously published studies. ${ }^{15}$ Although these germs exhibited variable resistance profiles, multi-resistant bacteria (Staphylococcus aureus) were uncommon $(4.5 \%)$, to the extent that the antimicrobial treatment administered to the majority of patients was successful.

There is a relationship between germs species and virulence, but with relation to the diabetic foot, there does not appear to be a clear relationship between type of pathogen and severity of infection. ${ }^{16}$ It is possible that this fact is related to the wide range of factors that act synergistically together in establishment and proliferation of lesions of the diabetic foot. ${ }^{5}$

Bacterial resistance was observed for several different drugs, but it was clindamycin, which is widely utilized in empirical regimes for treatment of the diabetic foot, to which bacteria were most often resistant (59\%). It should be pointed out that, in this study, anaerobic germs, which tend to be treated using clindamycin, were not investigated. Notwithstanding, it is evident that this drug should not be used in isolation, but in combination. De Vries et al. ${ }^{16}$ conducted a study to investigate utilization of clindamycin and the possibility of resistance, finding that empirical use of a combination of clindamycin with ciprofloxacin did not produce the desired results, with resistance of 15 to $22 \%$. The same author also warns of resistance to ciprofloxacin, which also had a high rate of resistant bacteria in our study $(28.7 \%)$.

Although we cannot define an ideal empirical treatment regime for the infected diabetic foot, knowledge of the most common germs and the most effective antibiotics is very useful information, especially when treating patients with severe infection and those who do not respond to initial treatment. ${ }^{17,18}$ Continuous monitoring of bacterial flora is desirable, to enable empirical treatment protocols to be updated.

Wider-ranging studies conducted at multiple centers are needed in order to determine sensitivity of specific pathogens and to compare profiles of resistance across different institutions and between inpatients and outpatients.

\section{CONCLUSIONS}

The infected ulcerations in patients with diabetic foot were most commonly associated with germs present in the community, particularly the enterococci. Hospital germs, which as a rule are more virulent, were less frequent. Bacteria exhibited resistance to a variety of groups of antimicrobials and resistance to orally administered drugs was more prevalent.

In more than half of cases, germs exhibited resistance to clindamycin, a drug widely used for empirical treatment of the diabetic foot, suggesting that empirical use of this drug may be less effective than other antimicrobials. While there were cases of multi-resistant bacteria, these were rare.

\section{REFERENCES}

1. Caiafa JS, Castro AA, Fidelis C, et al. Atenção integral ao portador de pé diabético. São Paulo: Sociedade Brasileira de Angiologia e Cirurgia Vascular; 2010. http://sbacv.com.br/pdf/manual-do-pediabetico-final.pdf. Acessado: 10/12/2013

2. Sociedade Brasileira de Diabetes - SBD. Diretrizes da Sociedade Brasileira de Diabetes. 3rd. ed. Itapevi: A. Araújo Silva Farmacêutica; 2009. p. $129-43$

3. Hobizal KB, Wukich DK. Diabetic foot infections: current concept review. Diabet Foot Ankle. 2012;3(0):1-8. http://dx.doi. org/10.3402/dfa.v3i0.18409. PMid:22577496 
4. Richard JL, Sotto A, Lavigne JP. New insights in diabetic foot infection. World J Diabetes. 2011;2(2):24-32. http://dx.doi. org/10.4239/wjd.v2.i2.24. PMid:21537457

5. Lavery LA, Armstrong DG, Wunderlich RP, Mohler MJ, Wendel CS, Lipsky BA. Risk factors for foot infections in individuals with diabetes. Diabetes Care. 2006;29(6):1288-93. http://dx.doi. org/10.2337/dc05-2425. PMid:16732010

6. Rezende KF, Nunes MAP, Melo NH, Malerbi D, Chacra AR, Ferraz $M B$. Internações por pé diabético: comparação entre o custo direto estimado e o desembolso do SUS. Arq Bras Endocrinol Metabol. 2008;52(3):523-30. http://dx.doi.org/10.1590/S000427302008000300013. PMid:18506278

7. Pitta GBB, Castro AA, Soares AMMN, et al. Perfil dos pacientes portadores de pé diabético atendidos no Hospital Escola José Carneiro e na Unidade de Emergência Armando Lages. J Vasc Bras. 2005;4:5-10.

8. Lipsky BA, Peters EJG, Senneville E, et al. Expert opinion on the management of infections in the diabetic foot. Diabetes Metab Res Rev. 2012;28(Suppl 1):163-78. http://dx.doi.org/10.1002/ dmrr.2248. PMid:22271739

9. Lipsky BA. Infections problems of the foot in diabeic patients. In: Bowker JH, Pfeifer MA, editors. Levin and O'Neal's The diabetic foot. 7th ed. Philadelphia: Mosby Elsevier; 2008. p. 305-18.

10. Lipsky BA, and the International consensus group on diagnosing and treating the infected diabetic foot. A report from the international consensus on diagnosing and treating the infected diabetic foot. Diabetes Metab Res Rev. 2004;20(S1, Suppl 1):S6877. http://dx.doi.org/10.1002/dmrr.453. PMid:15150818

11. Jeffcoate WJ, Lipsky BA, Berendt AR, et al, and the International Working Group on the Diabetic Foot. Unresolved issues in the management of ulcers of the foot in diabetes. Diabet Med. 2008;25(12):1380-9. http://dx.doi.org/10.1111/j.14645491.2008.02573.x. PMid:19046235

12. Dow G, Browne A, Sibbald RG. Infection in chronic wounds: controversies in diagnosis and treatment. Ostomy Wound Manage. 1999;45(8):23-7, 29-40, quiz 41-2. PMid: 10655866.

13. Bowler PG, Duerden BI, Armstrong DG. Wound microbiology and associated approaches to wound management. Clin Microbiol Rev. 2001;14(2):244-69. http://dx.doi.org/10.1128/CMR.14.2.244269.2001. PMid:11292638

14. Sotto A, Richard JL, Combescure C, et al. Beneficial effects of implementing guidelines on microbiology and costs of infected diabetic foot ulcers. Diabetologia. 2010;53(10):2249-55. http:// dx.doi.org/10.1007/s00125-010-1828-3. PMid:20571753
15. Carvalho CBM, Neto RM, Aragão LP, Oliveira MM, Nogueira $M B$, Forti $A C$. Pé diabético: análise bacteriológica de 141 casos. Arq Bras Endocrinol Metabol. 2004;48(3):406-13. http://dx.doi. org/10.1590/S0004-27302004000300012.

16. de Vries MG, Ekkelenkamp MB, Peters EJ. Are clindamycin and ciprofloxacin appropriate for the empirical treatment of diabetic foot infections? Eur J Clin Microbiol Infect Dis. 2014;33(3):453-6. http://dx.doi.org/10.1007/s10096-013-1977-7. PMid:24220766

17. Sader HS, Durazzo A. Terapia antimicrobiana nas infecções do pé diabético. J Vasc Bras. 2003;2:61-6.

18. Fernandes LF, Pimenta FC, Fernandes FF. Isolamento e perfil de suscetibilidade de bactérias de pé diabético e úlcera de estase venosa de pacientes admitidos no pronto-socorro do principal hospital universitário do estado de Goiás, Brasil. J Vasc Bras. 2007;6(3):211-7. http://dx.doi.org/10.1590/ S1677-54492007000300003.

Correspondence Alexandre Faraco Oliveira Rua Marechal Deodoro, 856 - Centro CEP 88500-000 - Lages (SC), Brazil Fone: +55 (49) 3224-3872 E-mail:afaraco@gmail.com

Author information AFO is a vascular surgeon. MSc in Human Aging from Universidade de Passo Fundo (UPF) and Board certified in Vascular Surgery from SBACV; Professor, School of Medicine, Universidade do Planalto Catarinense (UNIPLAC)

HOF is a vascular surgeon. Board certified in Vascular Surgery from Universidade de São Paulo (USP) and in Angiology and Vascular Surgery from SBACV; Vascular surgeon at Clínica Ana Carolina Lages.

Author contributions Conception and design: AFO, HOF Analysis and interpretation: AFO

Data collection: AFO Writing the article: AFO Critical revision of the article: AFO, HOF Final approval of the article*: AFO, HOF Statistical analysis: AFO Overall responsibility: AFO, HOF Obtained funding: None

*All authors have read and approved of the final version of the article submitted to I Vasc Bras. 